\title{
WILL THE REAL SOCIAL WORKER PLEASE STAND UP? \\ Defining criminal justice social work
}

\section{LEON HOLTZHAUSEN*}

leon.holtzhausen@uct.ac.za

The fundamental objective of this article is to urge a change in the conventional paradigms used to define the practice of social work in the field of criminal justice, and to set in motion a conversion to a unified paradigm of criminal justice social work. A unified paradigm is used here to refer to the multidimensional and multidisciplinary practice of social work in working with both those who offend and those who are victims of crime, in order to restore harm done and prevent further offending. This text is essentially nomenclatorial in nature, meaning, it deals with the naming and defining the specialisation of criminal justice social work as distinctly different from social work in general.

The last few years have seen a maelstrom of change and transformation of policy and programmes at all levels within the South African criminal justice sector. These include, among others, working with offenders and victims of crime through the use of restorative justice programmes, Victim-Offender-Mediation protocols, and a stronger focus on diversion of child and youth offenders out of criminal justice. Yet, despite the role that social workers play in these interventions, a widely accepted definition of social work in the field of criminal justice does not exist. This is notwithstanding the fact that historically, social workers have provided services to incarcerated individuals since the inception of the profession in $1904 .^{1}$

\footnotetext{
* Leon Holtzhausen is a senior lecturer in the Department of Social Development, College of Humanities, University of Cape Town. He specialises in criminal justice social work, violence prevention, and the treatment of substance abuse disorders.
}

The lack of a clear definition of criminal justice social work may be exacerbated by the short time given to social workers to prepare for, comprehend and deal with crime and delinquency. Research has shown that professionals are seldom prepared for social work practice in specialised settings like prisons and secure care facilities. ${ }^{2}$ To make matters worse, there is very little useful exchange of information between those who teach and those who employ social workers in criminal justice. Researchers and academics have not engaged sufficiently with the development and application of nomenclature for this field, leading to an underlying crisis of identity that needs resolution. ${ }^{3}$

\section{FRAGMENTED POLICY AND LEGISLATIVE FRAMEWORKS}

One reason for the crisis of identity is the polymorphous fragmenting of social work in the field of criminal justice into ever-smaller-subspecialities with overlapping policy and legislative 
responsibilities. For example, present statutory provisions for probation services in South Africa are contained in the Probation Services Act (No 116 of 1994), the Probation Services Amendment Act of 2002, the Child Care Act (No 74 of 1983), Criminal Procedure Act (No 51 of 1997) and the Child Justice Act (No 75 of 2008). The role of probation officers as investigators, supervisors, crime 'preventers', planners and implementers of programmes, and convenors and mediators in restorative justice initiatives, are described accordingly in each piece of legislation. ${ }^{4}$

Furthermore, forensic social workers function in Family Violence, Child Protection and Sexual Offences (FCS) units across South Africa. The FCS units, which exist in 176 policing areas countrywide, were established to conduct specialised investigations in all cases of sexual offences, domestic violence and child abuse. These perplexing sub-specialities spawn a multitude of disjointed professionals practicing social work in the same field, making use of selflimiting paradigms that impact adversely on service delivery to both offenders and victims of crime. A unified practice framework and understanding of criminal justice social work could change the way professionals engage with each other and those they serve, leading to integrated 'one stop' service delivery, as envisaged by the various policy and legislative frameworks that govern this sector.

\section{FRAGMENTED SERVICE DELIVERY}

The chaotic fragmentation of social work in the field of criminal justice is reminiscent of the 1956 American television game show To Tell the Truth. The show features a panel of four celebrities attempting to correctly identify a described contestant who has an unusual occupation. Towards the end of the show, the host would ask: 'Would the real..........please stand up?'

Finding the same professional working with the same client system, but in different settings at different times, claiming to be someone else, leads to doubtful validity of a scientific discipline. Depending on the time of day or place of meeting, offenders could be seeing a social worker for an assessment regarding their mental competency to understand their behaviour, their level of moral development, criminal capacity and ability to stand trial. Later the same day they could be meeting another social worker who makes recommendations concerning child custody and divorce proceedings and the placement of their emotionally disturbed child in a secure care facility, pending court proceedings. At some stage they might have an appointment with yet another social worker to discuss sentencing options and the possibility of being diverted to a community supervision sentence. Along the way they'll likely meet a social worker who will talk to them about the impact of their crime on the victim and engage in some form of restorative justice to try and minimise the harm of their offending behaviour and help them make amends. When they finally walk into court, a social worker may be there as an expert witness in their case, offering evidence of possible future risk and harm and making recommendations in relation to sentencing options. Will the real social worker please stand up?

These small artificially boundaried areas of social work in criminal justice are of questionable utility. Kirst-Ashman, by way of example, defines forensic social work as social work involving the law - both criminal and civil, and the legal system. ${ }^{5}$ Included in the tasks of the forensic social worker are the conduct of assessments regarding suspects' mental competency to understand their behaviour and stand trial; making recommendations concerning child custody, divorce, and the placement of emotionally disturbed or delinquent juveniles; preparing for court presentations as expert witnesses; and advocating for welfare rights. For Kirst-Ashman, forensic social work focuses predominantly on service delivery when offenders enter the criminal justice system, and adjudication (the process of legal sentencing and passing of judgement). Others, like Barker, recognise forensic social work as a 'specialised field of social work practice that is characterised by the social worker's primary function of providing expert testimony in courts of law' ${ }^{\prime}$ 
Then there is the vicarious use of the term probation officer. Some, like Morris, optimistically describe the goal of probation officers as involving people who receive a sentence of probation in community service, and steering them away from criminal behaviour. ${ }^{7}$ In contrast, others, like Annison et al, write about a 'new breed' of probation officer, more versed in control than care. ${ }^{8}$ This echoes Whitehead and Braswell's lamentation of the supposedly 'dark side' of contemporary probation officers:

\begin{abstract}
Probation officers have gone from social casework to urine testing, from brokerage activities to curfew monitoring, from acting as mentors to arresting for technical violations... probation officers have changed their ideal role model from John Augustus, acting as avuncular advisor, to Dirty Harry Callahan, waiting for a violation to 'make their day.'
\end{abstract}

In some countries, South Africa among them, the term correctional social work describes services delivered to offenders in prisons and community corrections settings. According to the Department of Correctional Services the core function of social work services in corrections is 'to assess the offender and provide needs-based programmes and services in order to enhance the adjustment, social functioning and reintegration of offenders back into the community. ${ }^{10}$ Duties include obtaining information from clients and their families to identify social, economic, emotional, health or physical problems and to determine eligibility for casework or other services.

Domestic violence social work is another example of a sub-speciality that has emerged with scant regard for overlapping concerns or the skills and needs found in the field of criminal justice social work. This despite the fact that social workers are the professionals most frequently contacted by survivors of domestic or intimate partner violence for emotional and physical problems, and sexual abuse, among others. Domestic violence services and shelters for survivors (women and children) have taken root in many places in South Africa often initiated and run by social workers. The role of domestic violence social work is generally described as developing interventions designed to deter abuse and rehabilitate abusers so they will not abuse again - clearly a criminal justice-related response.

Victim assistance counselling and support include various interventions intended to assist victims and witnesses of crime with the stressful and often traumatic process of testifying in court against offenders. Services include crisis counselling, assistance with making a legal complaint, support groups for survivors of violence and abuse, and temporary financial help.

\section{WHAT IS CRIMINAL JUSTICE SOCIAL WORK?}

Criminal justice social work (CJSW) is recognised as a specialised practice approach with three important functions unique to the field of criminal justice:

1. identifying and addressing offending behaviour

2. reducing the risk of re-offending

3. restoring those that have been injured and affected by crime.

\section{Identifying and addressing offending behaviour}

This entails the comprehensive assessment and detailed description of criminal behaviour in relation to crime causation and the factors that underlie offending, as well as delivering offencespecific programming, interventions and services to address this behaviour. Central to addressing offending behaviour is the belief that there are certain risk factors for crime situated in the life of the individual, the community and society that generate maladaptive behaviour. ${ }^{11}$ Raynor and Robinson believe that it is possible to isolate or identify the causes of an individual's offending whether they are related to his or her character, morality, personality, psychological makeup or choices - and intervene in ways that will remove those causes or otherwise effect positive changes in that individual. ${ }^{12}$ Accordingly, given the right interventions, programmes or 'treatments', it is assumed that offenders can be brought into line with a law-abiding 'norm.' ${ }^{13}$ 
Research literature is sufficiently robust to offer general suggestions about what should constitute good correctional assessment. For example, it is suggested that with offender assessments and preparole assessments, risk should be a major consideration. ${ }^{14}$ In risk assessments, therapists and correctional administrators assume that offenders have an invariant propensity to reoffend, which ranges from low risk (penny ante offending) to high risk (serious offending). Highrisk offenders should therefore be the main focus of intervention strategies. ${ }^{15}$ The goal of assessment is to assist in the treatment of offenders, and effective intervention depends on an accurate assessment. ${ }^{16}$ Offender assessment relates to the collection of detailed information about the offender's crime, as well as contributing factors of crime, offending behaviour, emotional and physical health, social roles and other factors bearing upon the offender's situation. ${ }^{17}$

\section{Reducing the risk of re-offending}

Ogloff and Davis observed that 'there is an everexpanding corpus of firm empirical support to show that offender rehabilitation can help reduce the risk of re-offending. ${ }^{\prime 18}$ Underpinning offender rehabilitation is the Risk-Need-Responsivity (RNR) model of Canadian researchers James Bonta, Don Andrews, and Paul Gendreau. ${ }^{19}$ The RNR model is perhaps the most influential model for the assessment and treatment of offenders. ${ }^{20}$

RNR is based on three principles:

1) the risk principle asserts that criminal behaviour can be reliably predicted and that treatment should focus on the higher risk offenders

2) the need principle highlights the importance of criminogenic needs in the design and delivery of treatment

3) the responsivity principle describes how the treatment should be provided.

According to Andrews, custodial treatment services should target multimodal criminogenic needs to develop offender-relevant treatment programmes. The factors placing the offender at future risk, often described as 'criminogenic', may be social or personal and have a causal or contributory role in offending acts, and should thus be the target of intervention. Adherence to the principles of risk and criminogenic needs depends upon the reliable and valid assessment of offender risks and needs.

Criminogenic needs are those aspects of an individual's functioning that give rise to his or her antisocial and criminal behaviour. A criminogenic factor may be located in any area where the offender has needs or deficits, where a reduction in the need or deficit would lead to a reduction in the risk of reconviction.

In other words, criminal justice social work focuses on those factors that place the offender at future risk for reoffending. All offenders display criminogenic and non-criminogenic needs. Criminogenic needs are divided into dynamic (changeable) and static (unchangeable) risk factors which, when reduced, are followed by reduced reoffending. Important dynamic risk factors include anger, prior treatment compliance, personality style, impulsiveness, psychopathy, cognitive impairment, violent fantasies, unemployment and substance abuse. ${ }^{21}$ If changed, these dynamic risk factors reduce the likelihood of criminal conduct. ${ }^{22}$ Research demonstrates that dynamic risk factors are reliable predictors of reoffending behaviour. Static risk factors (also known as 'historical factors'), which comprise factors such as criminal history, age and gender, are also reliable in predicting long-term recidivism risk for both general and sex offenders. ${ }^{23}$

\section{Restoring those that have been injured and affected by crime}

The role of criminal justice social work is transformed by shifting the focus from crime being a violation of the state, to crime being a violation of the person. From a restorative justice perspective, 'crime first of all is harm done to people and communities', says Zehr. Harm done must be repaired, and as a result victim support and healing become key priorities of social work intervention in the field of criminal justice. Implied within this restorative perspective in 
criminal justice social work is the need for offender accountability and responsibility. ${ }^{24}$ If crime is essentially about harm, then, according to Zehr, 'accountability must encourage offenders to understand the consequences of their actions. ${ }^{25}$ This is turn means that they have a responsibility to make things right as far as is possible, both concretely and symbolically.

In restoring the offender's capacity to function acceptably in society, offenders should understand and experience the consequences of their crimes, an experience that, according to Skelton, should lead to a change in their behaviour. This is both an ongoing process and an overarching aim of criminal justice social work. It entails providing both offenders and victims with appropriate assistance, through planned programming and intervention, to help them address the cost of crime. Also, as Marshall convincingly argues, 'restorative justice is a process whereby parties with a stake in a specific offence collectively resolve how to deal with the aftermath of the offence and its implications for the future.26

Often offenders need to be socially re-integrated into the community and their social connections reconstructed. Braithwaite and Mugford call this 'reforming the deviant through reconstructing his or her social ties. ${ }^{27}$ 'The social ties described here include those with family members and friends, but also potentially include a wider network of community ties and support', according to Raynor and Robinson. ${ }^{28}$ Reparative work - whether to a direct victim or the wider community - can also foster social reintegration..$^{29}$ Many victims also need re-integration into the community, as they often feel alienated and isolated as a result of crime. They need victim support, and the criminal justice social worker needs to provide this service.

\section{CONCLUSION}

Gain in any profession or scientific discipline can only be achieved by discarding some previously standard beliefs or procedures and, simultaneously, replacing those components of the previous paradigm with others. ${ }^{30}$ This article argued that there is a significant difference between the practices of social work and criminal justice social work, warranting a paradigm shift. The fundamental objective was to urge a change in the conventional paradigms used to practice social work in the field of criminal justice, and prompt a conversion to a unified paradigm of criminal justice social work. A new and more rigid definition of criminal justice social work was offered and explicated in an effort to create a unified practice framework for service delivery to those who offend, and those who are harmed.

To comment on this article visit

http://www.issafrica.org/sacq.php

\section{NOTES}

1. A Roberts and D Springer, Social work in juvenile and criminal justice settings (3rd Ed.), Springfield, IL: Charles C Thomas, 2007.

2. T Alleman and RL Gido, Turnstile Justice: Issues in American Corrections, Prentice Hall, New York, 1998.

3. B Butler and D Elliot, Teaching and Learning for Practice, England: Gower Publishing Company Limited, 1985; RR Middleman and GG Wood, Skills for Direct Practice in Social Work, United States of America: Columbia University Press, 1990; N Gould and I Taylor (eds.), Reflective Learning for Social Work, Aldershot: Arena, 1996; L Holtzhausen, Social Work Competency Requirements in Correctional Services, Unpublished D Litt et Phil. Department of Social Work, Faculty of Arts. Johannesburg: Rand Afrikaans University, 2003.

4. See Background to Probation Practice in South Africa, http://www.socdev.ecprov.gov.za/SubUnits/Crime\%20 Prevention\%20Unit/About\%20Us/Pages/Backgroundan dOverview.aspx (accessed 15 September 2011).

5. KK Kirst-Ashman and HH Grafton, Generalist Practice with Organisations and Communities, 2nd Ed. Belmont, CA: Brooks/Cole, 2002.

6. RL Barker and DM Branson, Forensic social work, New York: Haworth Press, 1993; R Barker, The Social Work Dictionary, 3rd Ed. Washington, DC: NASW Press, 1995.

7. T Morris, British Criminology: 1935-48, British Journal of Criminology 28, 2002, 20-34.

8. J Annison, T Eadie and C Knight, People First: Probation Officer Perspectives on Probation Work, Probation Journal, 55, 2008, 259.

9. JT Whitehead and MC Braswell, Future of Probation, Criminal Justice Review, 25(2), 2000.

10. Purpose of Social Work Services, http://www.dcs.gov. $\mathrm{za} /$ Services/SocialWorkServices.aspx

11. B Hamilton and J Coates, Perceived helpfulness and use of professional services by abused women, Journal of Family Violence 8, 1993, 313-324. Cited in FS Danis, Social Work Response to Domestic Violence: Encouraging News from a New Look, AFFILIA, 18(2), 2003, 177-191. 
12. P Raynor and G Robinson, Rehabilitation, Crime and Justice, Basingstoke: Palgrave Macmillan, 2005.

13. M Foucault, Discipline and Punish, London: Allen Lane, 1977; D. Garland, Punishment and Welfare: A History of Penal Strategies, Aldershot: Gower, 1985.

14. J Bonta, Offender risk assessment: guidelines for selection and use, Criminal Justice and Behavior 29, 2002, 355/379.

15. H Toch (ed.), Therapeutic communities in corrections, New York: Praeger, 2002.

16. P Matthews, Scientific Knowledge and the Aesthetic Appreciation of Nature, The Journal of Aesthetics and Art Criticism, 60(1), 2002, 37-48; C Meyer, The Ecosystems Perspective: Implications for Practice, in Meyer, C and Mattaini, M (eds), The Foundations of Social Work Practice: A Graduate Text, Washington, DC: NASW Press, 2001, 16-27.

17. HI Kaplan and BJ Shadock, Synopsis of Psychiatry. Behavioral Sciences / Clinical Psychiatry, 8th Ed, Baltimore: Williams and Wilkins, 1998.

18. JRO Ogloff and MR Davis, Advances in offender assessment and rehabilitation: Contributions of the risk_needs_responsivity approach, Psychology, Crime, and Law 10, 2004, 229-242; P Gendreau and R Ross, Effective correctional treatment: bibliotherapy for cynics, Crime and Delinquency 25, 1979, 463/489; P Gendreau, Offender rehabilitation: What we know and what needs to be done, Criminal Justice and Behavior 23, 1996, 144-161; Ross, R and Gendreau, P (eds.), Effective Correctional Treatment, Toronto: Butterworth, 1980; F Losel, Evaluating the effectiveness of correctional programs: Bridging the gap between research and practice, in Bernfeld, GA, Farrington, DP and Leschied, AW (eds.), Offender rehabilitation in practice, New York: John Wiley, 2001, 67-92; J McGuire, Evidence-based programming today, Paper presented at the International Community Corrections Association Annual Conference, Boston, MA, November 2002.

19. DA Andrews, The assessment of outcome in correctional samples, in Lambert, M, Christensen, E and DeJulio, S (eds.), The Measurement of Psychotherapy Outcome in Research and Evaluation, New York: Wiley, 1983, 160/201; DA Andrews, Principles of effective correctional programs, in LL Motiuk and R C Serin (eds.), Compendium 2000 on effective correctional programming, Ottawa:

Correctional Service of Canada, 2001, 9-17; DA Andrews, J Bonta and RD Hoge, Classification for effective rehabilitation: Rediscovering psychology, Criminal Justice and Behavior 17, 1990, 19-52; DA Andrews and J Bonta, The psychology of criminal conduct (3rd Ed.), Cincinnati, OH: Anderson, 2003; DA Andrews, J Bonta and JS Wormith, The recent past and near future of risk and/or need assessment, Crime and Delinquency 52, 2006, 7-27; DA Andrews and C Dowden, Managing correctional treatment for reduced recidivism: A meta-analytic review of program integrity, Legal and Criminological Psychology 10, 2005, 173-187; DA Andrews and J Bonta, The psychology of criminal conduct (3rd ed.), Cincinnati, OH: Anderson, 2007; K van Wormer, Social work today, 2002, Available at www.restorative justice.org/rj3/Full-text/ vanwormer/restorative
20. K Blanchette and SL Brown, The assessment and treatment of women offenders: An integrative perspective, West Sussex, U.K.: John Wiley \& Sons, 2006; T Ward, J Mesler and P Yates, Reconstructing the Risk-Need-Responsivity model: A theoretical elaboration and evaluation, Aggression and Violent Behavior 12, 2007, 8-228.

21. R Serin and S Kennedy, Treatment readiness and responsivity: Contributing to effective correctional programming, Research Report, Correctional Services Canada, 1997.

22. CR Hollin, Treatment programs for offenders: Meta-analysis, "what works" and beyond, International Journal of Law and Psychiatry 22, 2001, 361372; M Maguire, P Raynor, M Vanstone and J Kynch, Voluntary After-care and the Probation service: A Case of Diminishing Responsibility, Howard Journal of Criminal Justice 39, 2000, 234-48.

23. R Blackburn, The psychology of criminal conduct: Theory, research and practice, Toronto: John Wiley \& Sons, 1993; L Bradt, and M Bouverne-De Bie, 'Social Work and the Shift from Welfare to Justice, British Journal of Social Work, Advance Access, published 31 July 2007, DOI: 10.1093/BJSW/BCM072.

24. J Braithwaite and S Mugford, Conditions of Successful Reintegration Ceremonies, British Journal of Criminology 34(2), 1994, 139-71; RE Mann, SD Webster, C Schofield and WL Marshall, Approach versus avoidance goals in relapse prevention with sexual offenders, Sexual Abuse: A Journal of Research and Treatment, 16, 2004, 65-76.

25. H Zehr, Changing Lenses: A New Focus for Crime and Justice, Scottdale, PA: Herald Press, 1990.

26. A Skelton, Restorative Justice as a Framework for Juvenile Justice Reform: A South African Perspective, British Journal of Criminology, 42(3), 2002, 496-513; A Skelton and B Tshehla, Child Justice in South Africa. Pretoria: Institute for Security Studies, 2008.

27. WL Marshall, Therapist style in sexual offender treatment: Influences on indices of change, Sexual Abuse: A Journal of Research and Treatment, 17, 1999, 109-116; J Shapland, A Atkinson, H Atkinson, B Chapman, E Colledge, J Dignan, M Howes, J Johnstone, G Robinson and A Sorsby, Restorative Justice in Practice: The Second Report from the Evaluation of Three Schemes, The University of Sheffield Centre for Criminological Research Occasional Paper 2, Sheffield: Faculty of Law, 2006, Available at http:// www.ccr.group.shef.ac.uk/papers/ pdfs/Restorative_Justice_Report.pdf

28. Raynor and Robinson, Rehabilitation, Crime and Justice.

29. MS Umbreit, Victim-Offender Mediation in Canada: The Impact of an Emerging Social Work Intervention, International Social Work 42(2), 1999, 215-27; A Underdown, Strategies for Effective Supervision, Report of the HMIP What Works Project, London: Home Office, 1998.

30. Thomas S Kuhn, The Structure of Scientific Revolutions, 2nd Edition, Chicago, IL: University of Chicago Press, 1970. 